\title{
PENGARUH TINGKAT KETEBALAN MULSA JERAMI PADA PERTUMBUHAN DAN HASIL TANAMAN TALAS (Colocasia esculenta (L.) Schott var. Antiquorum)
}

\section{EFFECT OF STRAW MULCH THICKNESS ON GROWTH AND YIELD OF TARO (Colocasia esculenta (L.) Schott var. Antiquorum)}

\author{
Nur Edy Suminarti \\ Dosen Fakultas Pertanian Univ.Brawijaya, Malang \\ Jl. Veteran, Malang 65145 Jawa Timur, Indonesia \\ Korespondensi : nuredys@gmail.com
}

Diterima 19 Agustus 2015 /Disetujui 15 Desember 2015

\begin{abstract}
ABSTRAK
Umbi talas termasuk kelompok tanaman umbi-umbian yang mempunyai peran penting sebagai sumber bahan pangan yang sehat dan aman. Akibatnya, permintaan terus meningkat. Namun demikian, produktivitasnya masih rendah daripada potensinya yang telah mencapai 20,7 ton ha $^{-1}$. Oleh karena itu, perlu adanya peningkatan, dan salah satu cara yang dapat dilakukan adalah melalui aplikasi mulsa. Penelitian yang bertujuan untuk mendapatkan informasi tentang tingkat ketebalan mulsa jerami yang tepat pada budidaya tanaman talas telah dilakukan di Kebun Percobaan Universitas Brawijaya Malang. Penelitian menggunakan rancangan lingkungan Acak Kelompok dengan enam tingkat ketebalan mulsa sebagai perlakuan, yaitu : kontrol, ketebalan mulsa $1,5 \mathrm{~cm}, 3,0 \mathrm{~cm}, 4,5 \mathrm{~cm}, 6,0 \mathrm{~cm}$ dan $7,5 \mathrm{~cm}$. Pengumpulan data dilakukan secara destruktif. Uji $\mathrm{F}$ taraf $5 \%$ ditujukan untuk menguji pengaruh perlakuan, sedang perbedaan diantara perlakuan didasarkan pada nilai BNT taraf $5 \%$. Hasil penelitian menunjukkan bahwa pertumbuhan dan hasil tanaman talas serta lingkungan mikro yang lebih baik didapatkan pada ketebalan mulsa $4,5 \mathrm{~cm}-7,5 \mathrm{~cm}$. Tetapi yang lebih efektif dan efisien didapatkan pada penggunaan mulsa ketebalan $6 \mathrm{~cm}$ dengan hasil sebesar 10,54 ton $\mathrm{ha}^{-1}$ dan $\mathrm{B} / \mathrm{C} 1,76$.
\end{abstract}

Kata kunci: Komponen Pertumbuhan dan Hasil, Lingkungan Mikro, Mulsa, Talas

\begin{abstract}
Tuber of taro plays a significant role as healthy and safe food resources. As a result, its demand has increased recently. However, the level of taro tuber productivity is still low than the potential outcomes that can achieve up to 20 tons ha $^{-1}$. Therefore, it is necessary an improvement, one of them is through the application of mulch. Research aimed to find the proper thickness of straw mulch was conducted at UB experimental field located in Jatikerto, Malang. The study used randomized complete block design with thickness of straw mulch as the treatment, consisted of 6 levels, i.e: no mulch, straw mulch of $1.5 \mathrm{~cm}, 3 \mathrm{~cm}, 4.5 \mathrm{~cm}, 6 \mathrm{~cm}$ and $7.5 \mathrm{~cm}$. Data was collected destructively. $F$ test at $5 \%$ was used to determine the effect of treatment, while differences between treatments were referred to BNT at 5\%.The results showed that the growth and yield of taro and better microenvironment found in mulch
\end{abstract}


thickness of $4.5 \mathrm{~cm}-7.5 \mathrm{~cm}$. However, a more effective and efficient yield obtained on the use of mulch thickness of $6 \mathrm{~cm}$ with a yield of 10.54 ton ha ${ }^{-1}$ and B/C 1.76 .

Keywords : Growth and Yield Component, Micro Environment, Mulch, Taro

\section{PENDAHULUAN}

Tingginya nilai impor beras mengindikasikan rendahnya tingkat ketersediaan beras di Indonesia. Pernyataan ini dapat dibuktikan melalui Badan Pusat Statistik (2014) yang menginformasikan bahwa hingga bulan April 2014, Indonesia telah melakukan impor beras sebanyak 94,942 ton dari berbagai negara. Adapun beberapa hal yang mendasari terjadinya permasalahan tersebut antara lain adalah : (1) makin berkurangnya luas lahan pertanian, khususnya lahan basah yang merupakan tempat tanaman padi ditanam, (2) menurunnya daya dukung lahan akibat penggunaan pupuk maupun pestisida yang kurang ramah lingkungan secara berkesinambungan, serta (3) anomali iklim. Berdasar pada kenyataan tersebut, dan dalam upaya untuk memenuhi kecukupan pangan nasional, maka penganekaragaman sumber bahan pangan, khususnya bahan pangan lokal perlu dilakukan.

Umbi talas adalah salah satu komoditas umbi-umbian yang mempunyai prospek penting dan mempunyai nilai ekonomis tinggi dibandingkan jenis ubi-ubian lain seperti ketela rambat maupun ketela pohon. Ditinjau dari kandungan nutrisinya, umbi talas termasuk komoditas pangan yang sehat dan aman, dan tingkat keamanan tersebut terletak pada rendahnya kandungan karbohidrat $(22,25 \%)$, gula reduksi $(0,87 \%)$ serta kadar pati $(24,11 \%$ ) (Suminarti, 2009). Umbi talas dapat dikonsumsi segar dengan cara direbus, maupun diolah menjadi pati untuk berbagai bahan baku industri seperti bubur bayi maupun makanan orang tua (Onwueme, 1978). Selain itu, umbi talas dapat juga diolah menjadi berbagai macam olahan seperti perkedel, campuran soup, kolak maupun keripik talas. Berdasar pada tingginya pemanfaatan tersebut, mengakibatkan permintaan umbi talas terus meningkat. Namun demikian, permintaan tersebut belum dapat segera terpenuhi akibat rendahnya produktivitas umbi talas selama ini. Beberapa faktor yang diduga menjadi penyebab rendahnya hasil tersebut antara lain adalah : (1) Umumnya tanaman talas ditanam di lahan pekarangan sebagai tanaman sampingan dengan asupan nutrisi rendah, (2) mengingat tanaman talas ini umumnya ditanam di lahan pekarangan, maka tingkat ketersediaan air menjadi faktor pembatas utama (Sreekariyam and Thiruvananthapuram, 2003). Oleh karena itu, agar air yang berada pada kondisi terbatas tersebut tidak menjadikan kendala dalam usahatani talas di lahan pekarangan atau lahan kering, maka aplikasi mulsa sangat diperlukan.

Mulsa adalah suatu bahan, organik maupun an-organik yang dihamparkan di atas permukaan tanah yang berfungsi untuk : (1) menekan laju erosi maupun evaporasi tanah, dan (2) untuk menjaga kelembaban tanah. Ariffin (2005) menyatakan bahwa kelembaban tanah menggambarkan banyak sedikitnya uap air yang terkandung di dalam tanah, sehingga apabila kelembaban tanah tinggi, maka air yang tersedia di dalam tanah juga cukup banyak. Namun demikian, banyak sedikitnya air yang terkandung tersebut juga sangat ditentukan oleh 
tingkat ketebalan mulsa yang digunakan. Pada tingkat ketebalan mulsa tinggi, energi radiasi matahari yang diterima permukaan tanah rendah sebagai akibat tingginya tingkat halangan yang dilalui oleh radiasi matahari untuk mencapai suatu permukaan tanah. Akibatnya evaporasi berjalan lambat dan kelembaban tanah akan dapat dipertahankan (Suminarti, 2012). Di sisi lain, ketika tanah pada kondisi terbuka atau dengan tingkat ketebalan mulsa rendah, kelembaban tanah yang dihasilkan adalah rendah akibat tingginya energi radiasi matahari yang diterima oleh suatu permukaan tanah. Air, bagi tanaman mempunyai peran penting, diantaranya adalah untuk : (1) mengatur turgiditas sel yang menyebabkan kegiatan fotosintesa berlangsung, (2) sebagai reaktan yang menyebabkan unsurhara dapat diserap oleh akar tanaman, dan (3) sebagai media translokasi asimilat dari source ke bagian meristematis (Lerna and Mauromicale, 2006). Berdasar pada pentingnya peran air tersebut, maka kehilangan air tanah diharapkan hanya untuk memenuhi kepentingan transpirasi dan bukan untuk kepentingan evaporasi maupun evapotranspirasi gulma (Impron, 1999). Fungsi mulsa yang ketiga adalah untuk mengatur suhu tanah. Suhu tanah, selain berperan dalam menentukan laju tidaknya kecepatan evaporasi tanah, juga berperan dalam menentukan proses inisiasi maupun proses perkembangan umbi (Kozlowski, 1977). Mengingat hasil ekonomis tanaman talas terletak di dalam tanah, dan proses inisiasi atau pembentukan umbi sangat dipengaruhi oleh tinggi rendahnya suhu tanah, maka peran mulsa dalam mengendalikan dan mengatur suhu tanah adalah penting. Namun demikian, seberapa besar pengaruh penggunaan mulsa terhadap pengaturan suhu tanah, akan sangat dipengaruhi oleh tingkat ketebalan mulsa pada tanah. Sebagaimana yang telah dijelaskan pada uraian di atas bahwa ketika tingkat ketebalan mulsa tinggi, energi radiasi matahari yang diterima permukaan tanah adalah rendah, dan rendahnya energi radiasi matahari yang tersedia pada permukaan tersebut berkorelasi positif dengan suhu tanah yang ditimbulkan. Ketika energi radiasi yang tersedia di permukaan tanah rendah, maka suhu tanah yang dihasilkan juga rendah, dan sebaliknya (Rosernberg, 1974). Kozlowski ( 1977) mencatat bahwa proses inisiasi umbi pada tanaman ubi jalar dicapai pada kisaran suhu tanah antara $22-25^{\circ} \mathrm{C}$. Sehubungan dengan hal tersebut, diharapkan melalui uji ketebalan mulsa ini akan diperoleh informasi tentang tingkat ketebalan mulsa yang tepat dalam upaya untuk mendapatkan lingkungan mikro yang sesuai untuk pertumbuhan dan perkembangan tanaman talas sehingga produktivitas tanaman talas dapat ditingkatkan.

\section{BAHAN DAN METODE}

Penelitian yang bertujuan untuk mendapatkan informasi tentang tingkat ketebalan mulsa jerami yang tepat pada budidaya tanaman talas telah dilakukan pada bulan Mei sampai dengan Nopember 2014 di Kebun Percobaan Universitas Brawijaya yang terletak di Desa Jatikerto Kabupaten Malang. Lokasi terletak pada ketinggian $303 \mathrm{~m}$ dpl dan berupa lahan kering. Penelitian menggunakan rancangan lingkungan acak kelompok (RAK) sederhana, dan tingkat ketebalan mulsa sebagai perlakuan, terdiri dari 6 macam, yaitu : (1) kontrol, (2) mulsa ketebalan 1,5 cm, (3) 
mulsa ketebalan $3,0 \mathrm{~cm}$, (4) mulsa ketebalan 4,5 cm, (5) mulsa ketebalan 6,0 $\mathrm{cm}$ dan (6) mulsa ketebalan $7,5 \mathrm{~cm}$. Pengumpulan data dilakukan secara destruktif untuk komponen pertumbuhan yang mencakup pengukuran luas daun dan bobot kering total tanaman, dan komponen hasil yang mencakup penghitungan jumlah umbi per tanaman, bobot umbi per tanaman dan hasil umbi (ton ha ${ }^{-1}$ ). Pengamatan lingkungan dilakukan secara periodik selama pertumbuhan tanaman yang meliputi pengukuran suhu permukaan tanah dan suhu tanah kedalaman $30 \mathrm{~cm}$ pada pagi hari, kelembaban tanah pagi dan siang hari serta penghitungan analisis pertumbuhan tanaman yang mencakup Indeks Pembagian. Uji F taraf 5\% ditujukan untuk menguji pengaruh perlakuan, sedang perbedaan diantara perlakuan didasarkan pada nilai BNT taraf $5 \%$. Analisis regresi digunakan untuk melihat hubungan diantara variabel pengamatan (Gomez and Gomez, 1983).

\section{HASIL}

Secara umum, tingkat ketebalan mulsa jerami berpengaruh nyata pada semua parameter yang diamati, mencakup komponen pertumbuhan dan hasil maupun lingkungan mikronya.

\section{Komponen pertumbuhan}

\section{Luas daun}

Pengukuran luas daun ditujukan untuk mengetahui kapasitas tanaman dalam menghasilkan asimilat. Pada Tabel 1 disajikan rerata jumlah daun pada 6 tingkat ketebalan mulsa.

Tabel 1. Rerata luas daun pada enam tingkat ketebalan mulsa pada tiga umur pengamatan

\begin{tabular}{|c|c|c|c|}
\hline \multirow{2}{*}{ Perlakuan } & \multicolumn{3}{|c|}{ Luas daun $\left(\mathrm{cm}^{2}\right) /$ Umur pengamatan ( hst) } \\
\hline & 70 & 105 & 140 \\
\hline \multicolumn{4}{|c|}{ Tingkat ketebalan mulsa jerami } \\
\hline $0 \mathrm{~cm}$ (kontrol) & 465,60 a & 390,24 a & 454,07 a \\
\hline $1,5 \mathrm{~cm}$ & 501,26 a & $610,89 b$ & $521,65 a b$ \\
\hline $3,0 \mathrm{~cm}$ & 709,94 b & 696,32 bc & $586,63 b$ \\
\hline $4,5 \mathrm{~cm}$ & $795,13 \mathrm{bc}$ & $875,81 \mathrm{~cd}$ & $777,07 c$ \\
\hline $6,0 \mathrm{~cm}$ & $861,72 \mathrm{c}$ & $1064,69 \mathrm{de}$ & $1223,87 d$ \\
\hline $7,5 \mathrm{~cm}$ & $842,52 \mathrm{c}$ & $1154,36 \mathrm{e}$ & $1156,70 \mathrm{~d}$ \\
\hline BNT 5\% & 92,94 & 203,59 & 94,62 \\
\hline
\end{tabular}

Keterangan : Bilangan yang didampingi huruf yang sama pada kolom yang sama menunjukkan tidak berbeda nyata berdasarkan uji BNT taraf $p=5 \%$. Hst : hari setelah tanam

Berdasarkan Tabel 1 dapat dijelaskan bahwa pada umur pengamatan 70 hst, luas daun yang lebih sempit didapatkan pada perlakuan kontrol maupun pada penggunaan mulsa ketebalan $1,5 \mathrm{~cm}$, dan keduanya menghasilkan luas daun yang tidak berbeda nyata. Pertambahan luas daun akan terjadi apabila diikuti dengan peningkatan tingkat ketebalan mulsa pada berbagai tingkatan. Pertambahan luas daun sebesar $52,48 \% \quad\left(244,34 \mathrm{~cm}^{2}\right) ; \quad 70,77 \%$ $\left(329,53 \mathrm{~cm}^{2}\right) ; 85,08 \%\left(396,12 \mathrm{~cm}^{2}\right)$ dan $80,95 \%\left(376,92 \mathrm{~cm}^{2}\right)$ terjadi ketika tingkat ketebalan mulsa ditingkatkan, yaitu dari 
kontrol menjadi ketebalan $3 \mathrm{~cm}$ hingga 7,5 $\mathrm{cm}$. Sedangkan peningkatan ketebalan mulsa dari $1,5 \mathrm{~cm}$ menjadi $3 \mathrm{~cm}$ hingga 7,5 $\mathrm{cm}$, menyebabkan pertambahan luas daun masing-masing sebesar 41,63\% (208,68 $\mathrm{cm} 2) ; 58,63 \%(293,87 \mathrm{~cm} 2) ; 71,91 \%$ $(360,46 \mathrm{~cm} 2)$ dan sebesar 68,08\% $(341,26$ $\mathrm{cm}^{2}$ ). Luas daun memperlihatkan hasil yang tidak berbeda nyata pada penggunaan mulsa ketebalan $4,5 \mathrm{~cm}$ hingga $7,5 \mathrm{~cm}$, maupun pada ketebalan $3 \mathrm{~cm}$ dan $4,5 \mathrm{~cm}$. Pertambahan luas daun juga terjadi ketika tingkat ketebalan mulsa $3 \mathrm{~cm}$ ditingkatkan menjadi $6 \mathrm{~cm}$ dan $7,5 \mathrm{~cm}$. Pola hasil yang hampir sama dengan pengamatan umur 70 hst, dijumpai pada umur pengamatan 105 hst. Sedang pada umur pengamatan 140 hst, pada perlakuan kontrol dan penggunaan mulsa $1,5 \mathrm{~cm}$, luas daun yang dihasilkan tidak berbeda nyata, demikian pula pada penggunaan mulsa ketebalan 1,5 $\mathrm{cm}$ dan $3 \mathrm{~cm}$ serta pada ketebalan mulsa 6 $\mathrm{cm}$ dan $7,5 \mathrm{~cm}$. Peningkatan tingkat ketebalan mulsa secara nyata berdampak pada bertambahnya luas daun yang dihasilkan, dan ini terjadi ketika perlakuan kontrol ditingkatkan ketebalannya menjadi $3 \mathrm{~cm}$ hingga $7,5 \mathrm{~cm}$, dan ketika ketebalan mulsa dari $3 \mathrm{~cm}$ atau $4 \mathrm{~cm}$ ditingkatkan menjadi 6 hingga $7,5 \mathrm{~cm}$.

\section{Bobot kering total tanaman}

Tujuan pengukuran bobot kering total tanaman adalah untuk mengetahui banyak sedikitnya asimilat yang dapat dihasilkan oleh tanaman, dan merupakan cerminan kemampuan suatu tanaman dalam memanfaatkan faktor lingkungan. Pada Tabel 2 disajikan rerata bobot kering total tanaman pada enam tingkat ketebalan mulsa.

Tabel 2. Rerata bobot kering total tanaman pada enam tingkat ketebalan mulsa pada tiga umur pengamatan

\begin{tabular}{|c|c|c|c|}
\hline \multirow{2}{*}{ Perlakuan } & \multicolumn{3}{|c|}{ Bobot kering total tanaman (g)/ Umur pengamatan ( hst) } \\
\hline & 70 & 105 & 140 \\
\hline \multicolumn{4}{|c|}{ Tingkat ketebalan mulsa jerami } \\
\hline $0 \mathrm{~cm}$ (kontrol) & 26,04 a & 38,06 a & 44,01 a \\
\hline $1,5 \mathrm{~cm}$ & $38,41 \mathrm{~b}$ & $48,60 \mathrm{ab}$ & $60,13 b$ \\
\hline $3,0 \mathrm{~cm}$ & $48,23 \mathrm{c}$ & $58,75 \mathrm{bc}$ & 67,66 bc \\
\hline $4,5 \mathrm{~cm}$ & $59,04 d$ & 73,37 de & $76,58 \mathrm{~cd}$ \\
\hline $6,0 \mathrm{~cm}$ & $62,91 \mathrm{~d}$ & 82,85 e & $85,30 \mathrm{~d}$ \\
\hline $7,5 \mathrm{~cm}$ & $60,06 \mathrm{~d}$ & $70,43 \mathrm{~cd}$ & $80,66 \mathrm{~d}$ \\
\hline BNT 5\% & 8,64 & 11,95 & 12,02 \\
\hline
\end{tabular}

Keterangan : Bilangan yang didampingi huruf yang sama pada kolom yang sama menunjukkan tidak berbeda nyata berdasarkan uji BNT taraf $p=5 \%$. Hst : hari setelah tanam

Pada umur pengamatan $70 \mathrm{hst}$, bobot kering total tanaman yang paling rendah didapatkan pada perlakuan kontrol, sedang yang lebih tinggi didapatkan pada penggunaan ketebalan mulsa $4,5 \mathrm{~cm}$ hingga $7,5 \mathrm{~cm}$, dan ketiganya memperlihatkan hasil yang tidak berbeda nyata. Setiap pe- ningkatan satu level ketebalan mulsa, yaitu dari kontrol menjadi $1,5 \mathrm{~cm}$ dan dari $1,5 \mathrm{~cm}$ menjadi $3,0 \mathrm{~cm}$, menyebabkan bertambahnya bobot kering total tanaman masingmasing sebesar $47,50 \%(12,37 \mathrm{~g})$ dan sebesar $25,57 \%(9,82 \mathrm{~g})$. Hal ini juga terjadi ketika tingkat ketebalan mulsa $0 \mathrm{~cm}, 1,5 \mathrm{~cm}$ 
dan $3,0 \mathrm{~cm}$ ditingkatkan menjadi $4,5 \mathrm{~cm}, 6,0$ $\mathrm{cm}$ dan 7,5 cm, masing-masing pertambahan tersebut adalah sebesar $126,73 \%$ $(33,0 \mathrm{~g}) ; 141,59 \%(36,87 \mathrm{~g})$ dan $130,65 \%$ $(34,02$ g) untuk kontrol, dan sebesar $53,71 \%(20,63 \mathrm{~g}) ; 63,79 \%(24,5 \mathrm{~g})$ dan $56,37 \%$ (21,65 g) untuk ketebalan mulsa 1,5 $\mathrm{cm}$, serta sebesar $22,41 \%(10,81 \mathrm{~g}) ; 30,44 \%$ $(14,68 \mathrm{~g})$ dan $24,53 \%$ ( $11,83 \mathrm{~g})$ untuk ketebalan mulsa $3 \mathrm{~cm}$.

Pada umur pengamatan 105 hst, pada perlakuan kontrol, bobot kering total tanaman yang dihasilkan nyata lebih rendah $54,36 \%(20,69 \mathrm{~g}) ; 92,77 \%(35,31 \mathrm{~g})$; $117,68 \%(44,79 \mathrm{~g})$ dan $85,05 \%$ (32,37 g) jika dibandingkan dengan penggunaan mulsa ketebalan $3 \mathrm{~cm}$ hingga $7,5 \mathrm{~cm}$. Namun demikian, hasil yang diperoleh pada perlakuan kontrol tersebut memperlihatkan hasil yang tidak berbeda nyata dengan penggunaan mulsa ketebalan $1,5 \mathrm{~cm}$. Hal ini berlaku pula pada penggunaan mulsa ketebalan $1,5 \mathrm{~cm}$ dan $3, \mathrm{~cm}, 3 \mathrm{~cm}$ dan 7,5 $\mathrm{cm}$ dan pada ketebalan mulsa $4,5 \mathrm{~cm}$ dan 6 $\mathrm{cm}$.

Pada perlakuan kontrol, bobot kering total tanaman yang dihasilkan paling rendah untuk umur pengamatan 140 hst, dan memperlihatkan terjadinya peningkatan seiring tingkat ketebalan mulsa. Peningkatan ketebalan mulsa dari $0 \mathrm{~cm}$ menjadi $1,5 \mathrm{~cm}$ hingga $7,5 \mathrm{~cm}$, menyebabkan terjadinya pertambahan bobot kering total tanaman masing-masing sebesar 36,63\% (16,12 g ; 53,73\% (23,65 g); $74,01 \%$ (32,57 g); 93,82\% (41,29 g) dan $83,28 \%$ ( $36,65 \mathrm{~g})$. Namun demikian, hal ini tidak terjadi ketika ketebalan mulsa ditingkatkan dari $1,5 \mathrm{~cm}$ menjadi $3 \mathrm{~cm}$, atau dari $3 \mathrm{~cm}$ menjadi $4,5 \mathrm{~cm}$, maupun dari 4,5 $\mathrm{cm}$ hingga $7,5 \mathrm{~cm}$. Bobot kering total tanaman memperlihatkan terjadinya peningkatan ketika tingkat ketebalan mulsa ditingkatkan dari $1,5 \mathrm{~cm}$ menjadi $4,5 \mathrm{~cm}$ hingga $7,5 \mathrm{~cm}$, maupun dari $3 \mathrm{~cm}$ menjadi 6 $\mathrm{cm}$ dan $7,5 \mathrm{~cm}$.

\section{Komponen hasil}

Komponen hasil pada tanaman talas meliputi pengukuran jumlah umbi per tanaman, bobot umbi per tanaman dan hasil panen (ton ha ${ }^{-1}$ ), dan hasil ini disajikan pada Tabel 3 .

Tabel 3. Rerata jumlah umbi per tanaman, bobot umbi per tanaman dan hasil panen (ton ha-1) pada enam tingkat ketebalan mulsa pada saat panen

\begin{tabular}{lccc}
\hline \multicolumn{1}{c}{ Perlakuan } & $\begin{array}{c}\text { Jumlah umbi } \\
\text { per tanaman }\end{array}$ & $\begin{array}{c}\text { Bobot umbi per } \\
\text { tanaman }(\mathrm{g})\end{array}$ & $\begin{array}{c}\text { Hasil panen (ton } \\
\text { ha }^{-1} \text { ) }\end{array}$ \\
\hline Tingkat ketebalan mulsa jerami & & & \\
$0 \mathrm{~cm}$ (kontrol) & $7,73 \mathrm{a}$ & $129,03 \mathrm{a}$ & $3,82 \mathrm{a}$ \\
$1,5 \mathrm{~cm}$ & $8,86 \mathrm{a}$ & $181,30 \mathrm{a}$ & $5,37 \mathrm{ab}$ \\
$3,0 \mathrm{~cm}$ & $10,73 \mathrm{~b}$ & $243,23 \mathrm{~b}$ & $7,21 \mathrm{bc}$ \\
$4,5 \mathrm{~cm}$ & $14,00 \mathrm{c}$ & $276,13 \mathrm{bc}$ & $8,18 \mathrm{~cd}$ \\
$6,0 \mathrm{~cm}$ & $14,46 \mathrm{c}$ & $355,63 \mathrm{~d}$ & $10,54 \mathrm{e}$ \\
$7,5 \mathrm{~cm}$ & $13,33 \mathrm{c}$ & $316,30 \mathrm{~cd}$ & $9,37 \mathrm{de}$ \\
\hline \multicolumn{4}{c}{ BNT 5\% } \\
\hline
\end{tabular}

Keterangan : Bilangan yang didampingi huruf yang sama pada kolom yang sama menunjukkan tidak berbeda nyata berdasarkan uji BNT taraf $p=5 \%$. 
Tabel 3 memperlihatkan bahwa jumlah umbi per tanaman yang lebih sedikit didapatkan pada perlakuan kontrol dan penggunaan mulsa ketebalan $1,5 \mathrm{~cm}$, sedang yang lebih banyak didapatkan pada penggunaan mulsa ketebalan $4,5 \mathrm{~cm}$ hingga $7,5 \mathrm{~cm}$. Peningkatan satu level ketebalan mulsa, yaitu dari kontrol $(0 \mathrm{~cm})$ menjadi 1,5 $\mathrm{cm}$ tidak diikuti dengan pertambahan jumlah umbi secara nyata. Hal ini diperlihatkan pula pada penggunaan mulsa ketebalan 4,5 cm, $6 \mathrm{~cm}$ dan 7,5 cm. Namun demikian, ketika ketebalan mulsa ditingkatkan yaitu dari $0 \mathrm{~cm}$ dan $1,5 \mathrm{~cm}$ menjadi $3 \mathrm{~cm}$ hingga $7,5 \mathrm{~cm}$, jumlah umbi mengalami pertambahan masing-masing sebesar 38,81\% (3 umbi) ; 81,11\% (6,27 umbi) ; 87,06\% (6,73 umbi) dan 72,45\% (5,6 umbi) untuk kontrol, dan sebesar $21,11 \%$ (1,87 umbi) ; 58,01\% (5,14 umbi) ; 63,21\% (5,6 umbi) dan 50,45\% (4,47 umbi) untuk ketebalan mulsa $1,5 \mathrm{~cm}$. Jumlah umbi juga menunjukkan terjadinya pertambahan ketika ketebalan mulsa ditingkatkan dari 3 $\mathrm{cm}$ menjadi $4,5 \mathrm{~cm}$ hingga $7,5 \mathrm{~cm}$.

Pada pengamatan bobot umbi per tanaman dan hasil panen per hektar memperlihatkan terbentuknya pola yang sama. Umumnya bobot umbi per tanaman dan hasil panen per hektar yang lebih rendah didapatkan pada kontrol dan penggunaan mulsa ketebalan $1,5 \mathrm{~cm}$, dan keduanya menunjukkan hasil yang tidak berbeda nyata. Pada saat ketebalan mulsa ditingkatkan, yaitu dari $0 \mathrm{~cm}$ dan $1,5 \mathrm{~cm}$ menjadi $3 \mathrm{~cm}$ hingga $7,5 \mathrm{~cm}$, bobot umbi per tanaman maupun hasil panen per hektar memperlihatkan terjadinya pertambahan. Tetapi, ketika ketebalan mulsa ditingkatkan, yaitu dari $3 \mathrm{~cm}$ menjadi 4,5 $\mathrm{cm}$, maupun dari $4,5 \mathrm{~cm}$ menjadi $7,5 \mathrm{~cm}$ dan dari $6 \mathrm{~cm}$ menjadi $7,5 \mathrm{~cm}$, bobot umbi per tanaman maupun hasil panen per hektar tidak memperlihatkan terjadinya pertambahan secara nyata. Pertambahan akan terjadi ketika ketebalan mulsa ditingkatkan, yaitu dari $3 \mathrm{~cm}$ menjadi $6 \mathrm{~cm}$ dan menjadi $7,5 \mathrm{~cm}$. Pertambahan tersebut masingmasing sebesar $46,21 \%(112,4 \mathrm{~g})$ dan $30,04 \%$ (73,07 g) untuk bobot umbi per tanaman, dan sebesar 46,19\% (3,33 ton ha1) dan $29,96 \%$ (2,16 ton ha-1) untuk hasil panen. Bobot umbi per tanaman maupun hasil panen per hektar menunjukkan hasil yang tidak berbeda nyata pada penggunaan mulsa ketebalan $6 \mathrm{~cm}$ dan $7,5 \mathrm{~cm}$.

\section{Komponen lingkungan}

\section{Kelembaban tanah}

Pengukuran kelembaban tanah dilakukan pada pagi hari pukul 06.00 dan siang hari pukul 13.00 yang berfungsi untuk mendapatkan gambaran tinggi rendahnya kandungan air tanah. Rerata pengukuran kelembaban tanah pagi dan siang hari pada enam tingkat ketebalan mulsa disajikan pada Tabel 4.

Tabel 4 memperlihatkan bahwa kelembaban tanah pagi hari yang paling rendah didapatkan pada perlakuan kontrol, dan memperlihatkan terjadinya peningkatan dengan ditingkatkannya tingkat ketebalan mulsa dari kontrol hingga ketebalan $7,5 \mathrm{~cm}$. Tetapi, ketika ketebalan mulsa ditingkatkan, yaitu dari $1,5 \mathrm{~cm}$ hingga menjadi $4,5 \mathrm{~cm}$ atau dari $3 \mathrm{~cm}$ hingga menjadi $6 \mathrm{~cm}$ dan dari $4,5 \mathrm{~cm}$ menjadi 6 dan $7,5 \mathrm{~cm}$, tidak diikuti dengan peningkatan kelembaban tanah secara nyata. Namun demikian, ketika tingkat ketebalan mulsa ditingkatkan, yaitu dari $1,5 \mathrm{~cm}$ menjadi 6 hingga $7,5 \mathrm{~cm}$ atau dari $3 \mathrm{~cm}$ menjadi $7,5 \mathrm{~cm}$, kelembaban tanah mengalami pertambahan masingmasing sebesar $2,55 \%, 3,49 \%$ dan $2,77 \%$. 
Tabel 4. Rerata kelembaban tanah pagi dan siang hari pada enam tingkat ketebalan mulsa pada umur pengamatan 99 hst

\begin{tabular}{|c|c|c|}
\hline Perlakuan & Kelembaban tanah pagi (\%) & Kelembaban tanah siang (\%) \\
\hline $0 \mathrm{~cm}$ (kontrol) & $68,17 \mathrm{a}$ & 24,67 a \\
\hline $1,5 \mathrm{~cm}$ & $71,67 \mathrm{~b}$ & $26,83 a b$ \\
\hline $3,0 \mathrm{~cm}$ & $72,17 \mathrm{bc}$ & $30,00 \mathrm{bc}$ \\
\hline $4,5 \mathrm{~cm}$ & $72,83 \mathrm{bcd}$ & $31,00 \mathrm{bc}$ \\
\hline $6,0 \mathrm{~cm}$ & $73,50 \mathrm{~cd}$ & $33,17 c$ \\
\hline $7,5 \mathrm{~cm}$ & $74,17 \mathrm{~d}$ & $34,33 \mathrm{c}$ \\
\hline BNT 5\% & 1,65 & 5,17 \\
\hline
\end{tabular}

Pada pengamatan kelembaban tanah siang, perlakuan kontrol maupun penggunaan mulsa ketebalan $1,5 \mathrm{~cm}$, kelembaban tanah yang dihasilkan tidak berbeda nyata dan nyata lebih rendah dibandingkan dengan penggunaan mulsa ketebalan $3 \mathrm{~cm}$ hingga 7,5 cm untuk kontrol dan dengan ketebalan 6 hingga $7,5 \mathrm{~cm}$ untuk penggunaan mulsa $1,5 \mathrm{~cm}$. Pada tingkat ketebalan mulsa $3 \mathrm{~cm}$ hingga $7,5 \mathrm{~cm}$ dan $1,5 \mathrm{~cm}$ hingga $4,5 \mathrm{~cm}$, kelembaban tanah siang yang dihasilkan tidak berbeda nyata.

\section{Suhu tanah}

Pengamatan suhu tanah dilakukan pada pukul 6 pagi yang mencakup pengukuran suhu permukaan tanah dan kedalaman 30 $\mathrm{cm}$. Adapun tujuannya adalah untuk mendapatkan gambaran suhu tanah malam hari yang sangat berpengaruh dalam proses pembentukan dan perkembangan umbi. Pada Tabel 5 disajikan rerata suhu permukaan dan kedalaman $30 \mathrm{~cm}$ pagi.

Tabel 5. Rerata suhu permukaan tanah dan suhu tanah pada kedalaman $30 \mathrm{~cm}$ pada pagi hari pada enam tingkat ketebalan mulsa pada umur pengamatan $99 \mathrm{hst}$

\begin{tabular}{lcc}
\hline Perlakuan & Suhu permukaan tanah $\left({ }^{\circ} \mathrm{C}\right)$ & Suhu tanah kedalaman $30 \mathrm{~cm}\left({ }^{\circ} \mathrm{C}\right)$ \\
\hline $0 \mathrm{~cm}$ (kontrol) & $24,37 \mathrm{e}$ & $23,17 \mathrm{e}$ \\
$1,5 \mathrm{~cm}$ & $23,67 \mathrm{de}$ & $22,33 \mathrm{~d}$ \\
$3,0 \mathrm{~cm}$ & $23,17 \mathrm{~cd}$ & $21,83 \mathrm{~cd}$ \\
$4,5 \mathrm{~cm}$ & $22,80 \mathrm{bc}$ & $21,50 \mathrm{bc}$ \\
$6,0 \mathrm{~cm}$ & $22,40 \mathrm{ab}$ & $21,00 \mathrm{ab}$ \\
$7,5 \mathrm{~cm}$ & $21,83 \mathrm{a}$ & $20,17 \mathrm{a}$ \\
\hline BNT 5\% & 0,75 & 0,72 \\
\hline
\end{tabular}

Keterangan : Bilangan yang didampingi huruf yang sama pada kolom yang sama menunjukkan tidak berbeda nyata berdasarkan uji BNT taraf $p=5 \%$, hst : hari setelah tanam

Tabel 5 memperlihatkan bahwa suhu permukaan tanah yang lebih tinggi didapatkan pada kontrol maupun pada penggunaan mulsa ketebalan $1,5 \mathrm{~cm}$, dan keduanya memperlihatkan hasil yang tidak berbeda nyata. Setiap peningkatan $3 \mathrm{~cm}$ ketebalan mulsa, yaitu dari kontrol menjadi $3 \mathrm{~cm}$, dan dari $3 \mathrm{~cm}$ menjadi $6 \mathrm{~cm}$ maupun dari $1,5 \mathrm{~cm}$ menjadi $4,5 \mathrm{~cm}$ serta dari 4,5 $\mathrm{cm}$ menjadi $7,5 \mathrm{~cm}$ mengakibatkan turunnya suhu permukaan tanah masingmasing sebesar $1,2^{\circ} \mathrm{C} \quad(4,92 \%), \quad 0,77^{\circ} \mathrm{C}$ 
$(3,32 \%), 0,87^{\circ} \mathrm{C}(3,68 \%)$ dan $0,97^{\circ} \mathrm{C}(4,25 \%)$. Namun demikian, hal tersebut tidak terjadi pada setiap peningkatan $1,5 \mathrm{~cm}$ ketebalan mulsa. Suhu permukaan tanah yang terjadi pada kontrol memperlihatkan hasil yang tidak berbeda nyata dengan penggunaan mulsa ketebalan $1,5 \mathrm{~cm}$. Demikian pula untuk penggunaan mulsa ketebalan $1,5 \mathrm{~cm}$ dan $3 \mathrm{~cm}, 3 \mathrm{~cm}$ dengan $4,5 \mathrm{~cm} ; 4,5 \mathrm{~cm}$ dengan $6 \mathrm{~cm}$ dan $6 \mathrm{~cm}$ dengan $7,5 \mathrm{~cm}$. Pola yang hampir sama dari hasil pengamatan suhu permukaan tanah terjadi pada hasil pengamatan suhu tanah kedalaman $30 \mathrm{~cm}$. Namun demikian, suhu tanah kedalaman 30 $\mathrm{cm}$ yang tertinggi didapatkan pada perlakuan kontrol.

\section{PEMBAHASAN}

Lingkungan mikro tanaman adalah suatu kondisi lingkungan yang terjadi di sekitar tanaman dan umumnya sangat dipengaruhi oleh perilaku tanaman.

Hasil penelitian menunjukkan bahwa penggunaan mulsa jerami memberi pengaruh nyata pada seluruh parameter yang diamati. Pada komponen lingkungan, penggunaan mulsa jerami ketebalan $6 \mathrm{~cm}$ dan $7,5 \mathrm{~cm}$, suhu tanah yang dihasilkan nyata lebih rendah dibandingkan dengan perlakuan yang lain, baik untuk suhu permukaan tanah pagi maupun untuk suhu tanah pagi kedalaman $30 \mathrm{~cm}$. Lebih rendahnya suhu tanah pagi tersebut, khususnya pada kedalaman $30 \mathrm{~cm}$ akan memberi kontribusi besar dalam proses pembentukan dan pembesaran umbi. Hal ini karena pengukuran suhu tanah pagi dapat dijadikan sebagai gambaran fluktuasi suhu yang terjadi pada malam hari. Pada malam hari, umumnya tanaman akan melakukan respirasi, dan kecepatannya sangat dipengaruhi oleh tinggi rendahnya suhu (Tjondronegoro et al., 1981). Pada saat suhu tinggi, laju respirasi berlangsung lebih cepat dibandingkan ketika suhu pada malam hari rendah. Lebih tingginya respirasi tersebut akan berdampak pada berkurangnya asimilat yang telah dialokasikan ke bagian umbi, karena respirasi merupakan proses pembongkaran karbohidrat menjadi energi pertumbuhan. Akibatnya hasil panen yang diperoleh rendah, dan hal ini telah dibuktikan dengan hasil penelitian yang memperlihatkan bahwa untuk tanaman yang diberi mulsa jerami ketebalan $6 \mathrm{~cm}$ dan 7,5 cm, komponen pertumbuhan yang mencakup luas daun (Tabel 1), bobot kering total tanaman (Tabel 2), maupun komponen hasil (Tabel 3) nyata lebih tinggi dibandingkan dengan perlakuan lainnya, terutama terhadap kontrol. Hasil analisis regresi menunjukkan terdapatnya hubungan nyata antara suhu tanah pagi kedalaman $30 \mathrm{~cm}(\mathrm{X})$ dengan hasil umbi per hektar (Y) yang diberikan melalui persamaan : $Y=-0,63 X^{2}+24,9 X-234,22$ ; $R^{2}=0,90$. Tingginya nilai koefisien determinasi $\left(R^{2}\right)$ disini mengindikasikan bahwa $90 \%$ dari hasil umbi sangat dipengaruhi oleh suhu tanah pagi, khususnya suhu tanah pagi kedalaman 30 $\mathrm{cm}$. Berdasarkan persamaan kuadratik tersebut dapat ditentukan suhu tanah pagi optimum adalah sebesar $19,76^{\circ} \mathrm{C}$ dengan hasil umbi sebanyak 11,82 ton umbi ha ${ }^{-1}$. Di sisi lain, dengan lebih rendahnya suhu tanah pagi tersebut menyebabkan kelembaban tanah yang dihasilkan adalah tinggi. Bentuk dan pola hubungan antara suhu tanah pagi dengan kelembaban tanah pagi sebagaimana disajikan dalam Gambar 1.

Berdasar pada persamaan tersebut (dalam Gambar 1) dapat dijelaskan bahwa dengan semakin tinggi suhu tanah, maka kelembaban tanah yang dihasilkan semakin 
rendah, dan rendahnya nilai kelembaban tanah tersebut merupakan cerminan rendahnya air yang terkandung di dalam tanah. Ariffin (2005) menyatakan bahwa salah satu fungsi mulsa adalah untuk menjaga kelembaban tanah, dan tinggi rendahnya sangat dipengaruhi oleh tebal tipisnya mulsa maupun banyak sedikitnya energi yang tersedia pada permukaan tanah. Pada tanah terbuka (tanpa mulsa), energi radiasi yang diterima permukaan tanah adalah lebih tinggi dibandingkan dengan tanah yang tertutup mulsa. Hal ini sebagai akibat rendahnya tingkat halangan yang dilalui oleh energi radiasi tersebut ketika akan mencapai permukaan tanah (Rosernberg, 1974). Tingginya energi radiasi yang diterima permukaan tanah tersebut menyebabkan laju evaporasi tinggi sehingga kehilangan air melalui permukaan tanah maupun gulma juga tinggi, akibatnya air yang tersimpan di dalam tanah adalah rendah. Hasil penelitian Suminarti dan Sulem (2009) membuktikan adanya hubungan antara intensitas energi radiasi yang diterima permukaan tanah $(\mathrm{X})$ dengan kelembaban tanah ( $\mathrm{Y}$ ) yang diberikan melalui persamaan $Y=-0,5 X+84,89\left(R^{2}=\right.$ $0,97 *)$. Persamaan tersebut menjelaskan bahwa dengan semakin tinggi intensitas radiasi yang diterima permukaan tanah, maka semakin rendah kelembaban tanah yang ditimbulkannya. Pada uraian di atas telah dijelaskan bahwa kelembaban tanah menggambarkan banyak sedikitnya air yang terkandung di dalam tanah, sehingga apabila kandungan air tanah rendah maka aktifitas fisiologis tanaman akan terganggu. Hal ini sangat terkait dengan pentingnya peran air bagi tanaman. Impron (1999) menyatakan bahwa air berfungsi sebagai senyawa pelarut, yaitu untuk melarutkan unsur hara agar dapat diserap dan dimanfaatkan oleh tanaman. Air juga berfungsi sebagai senyawa pengangkut, yaitu untuk mentranslokasikan asimilat dari source ke bagian yang mengalami pembelahan (meristematis) yang menyebabkan terjadinya pertambahan ukuran organ tanaman. Selain itu, air juga berfungsi untuk mengatur proses membuka dan menutupnya stomata.

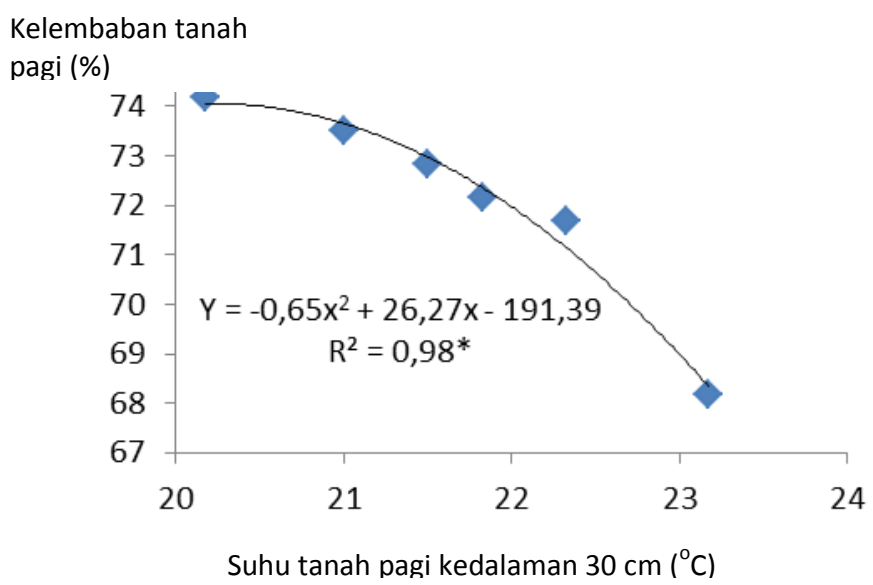

Gambar 1. Bentuk dan pola hubungan antara suhu tanah pagi kedalaman $30 \mathrm{~cm}$ dengan kelembaban tanah pagi 
Pada kondisi ketersediaan air tanah rendah, tanaman akan segera melakukan strategi dengan menutup stomata yang berfungsi untuk mengurangi kehilangan air dari dalam tubuh tanaman.Tetapi di sisi lain, cara adaptasi ini cukup merugikan tanaman karena menyebabkan laju fotosintesa menurun (Tol et al., 2010). Turunnya laju fotosintesa ini mengakibatkan rendahnya asimilat yang dapat dihasilkan oleh tanaman. Sementara asimilat merupakan energi, baik energi untuk pertumbuhan, maupun untuk energi cadangan. Oleh karena itu, apabila tanaman mengalami kahat air, maka proses deferensiasi pada meristem apikal akan terhambat sebagai akibat terhambatnya proses pembelahan, perluasan maupun perpanjangan sel ( lerna and Mauromicale, 2006). Akibatnya, kecepatan proses perkembangan tanaman menurun yang dapat ditunjukkan melalui terhambatnya proses perluasan daun (Slatyer, 1969). Hasil penelitian menunjukkan bahwa tanaman yang tanpa diberi mulsa maupun yang diberi mulsa ketebalan $1,5 \mathrm{~cm}$, luas daun yang dihasilkan lebih sempit (Tabel 1). Sementara, daun merupakan organ assimilatory penting bagi tanaman, dan luas daun menggambarkan kapasitas tanaman untuk menghasilkan asimilat. Oleh karena itu apabila luas daun sempit, maka asimilat yang dihasilkan juga rendah, dan hal ini telah dibuktikan melalui hasil penelitian yang menunjukkan bahwa bobot kering total tanaman yang lebih rendah juga didapatkan pada tanaman yang tanpa diberi mulsa maupun yang diberi mulsa dengan ketebalan 1,5 cm (Tabel 2). Hasil analisis regresi membuktikan terdapatnya hubungan nyata antara luas daun $(X)$ dengan bobot kering total tanaman (Y) yang diberikan melalui persamaan : $Y=-0,0001 X^{2}+0,23 X-32,96$, $\mathrm{R}^{2}=0,98$.

Hasil merupakan fungsi dari partumbuhan, dan salah satunya sangat ditentukan oleh banyak sedikitnya asimilat yang dihasilkan dan kemampuan tanaman dalam mengalokasikan asimilat tersebut ke bagian organ penyimpan (umbi). Hasil penelitian menunjukkan bahwa jumlah umbi per tanaman yang lebih sedikit didapatkan pada tanaman yang tanpa diberi mulsa maupun yang diberi mulsa dengan ketebalan $1,5 \mathrm{~cm}$. Rendahnya hasil tersebut sangat terkait dengan rendahnya asimilat yang dihasilkan sebagai akibat lebih sempitnya organ assimilatory yang dapat dibentuk (luas daun). Mengingat bahwa hasil ekonomis suatu tanaman juga sangat ditentukan oleh kemampuan suatu tanaman dalam mengalokasikan asimilatnya ke bagian umbi, dan diketahui bahwa nilai IP untuk ke dua perlakuan tersebut adalah rendah, masingmasing sebesar 0,64 dan 0,66, maka asimilat yang disimpan di dalam umbi juga rendah. Akibatnya, jumlah umbi yang dihasilkan juga rendah (Tabel 3). Indeks pembagian (IP) menggambarkan banyaknya asimilat yang dapat dialokasikan ke bagian organ penyimpan (umbi) per total asimilat yang dihasilkan (Suminarti, 2011). Mengingat jumlah umbi yang dihasilkan tersebut rendah, maka bobot umbi per tanaman yang didapatkan juga rendah. Rendahnya bobot umbi tersebut berdampak pula pada lebih rendahnya hasil yang diperoleh pada kedua perlakuan tersebut (Tabel 3). Sedang hasil yang lebih tinggi didapatkan pada tanaman yang diberi mulsa ketebalan $4,5 \mathrm{~cm} ; 6 \mathrm{~cm}$ dan $7,5 \mathrm{~cm}$, dan ketiganya memperlihatkan hasil yang tidak berbeda nyata. Sehubungan dengan hal tersebut dan untuk menentukan ketebalan mulsa yang efisien dan efektif 
dalam upaya untuk meningkatkan hasil tanaman talas, maka penghitungan analisis usahatani perlu dilakukan, dan berdasarkan hasil perhitungan tersebut didapatkan bahwa aplikasi mulsa jerami dengan ketebalan $6 \mathrm{~cm}$ adalah lebih efisien dan efektif karena mempunyai nilai $\mathrm{B} / \mathrm{C}$ paling tinggi, yaitu sebesar 1,76 kemudian diikuti dengan penggunaan mulsa jerami ketebalan $7,5 \mathrm{~cm}, 4,5 \mathrm{~cm}, 3 \mathrm{~cm}, 1,5 \mathrm{~cm}$ dan kontrol, masing-masing dengan $\mathrm{B} / \mathrm{C}$ sebesar 1,38 ; 1,$20 ; 0,99 ; 0,53$ dan 0,12 .

\section{SIMPULAN}

Berdasar pada hasil penelitian tersebut, maka dapat disimpulkan bahwa :

1. Aplikasi mulsa jerami berpengaruh nyata pada lingkungan mikro tanaman, khususnya kelembaban tanah dan suhu tanah serta pertumbuhan dan hasil tanaman talas.

2. Penggunaan mulsa jerami ketebalan 4,5 $\mathrm{cm} ; 6 \mathrm{~cm}$ dan 7,5 cm, menghasilkan lingkungan mikro (kelembaban tanah dan suhu tanah) serta pertumbuhan dan hasil yang tidak berbeda nyata dan nyata lebih baik dibandingkan penggunaan mulsa jerami ketebalan $3 \mathrm{~cm}, 1,5 \mathrm{~cm}$ dan kontrol.

3. Penggunaan mulsa jerami ketebalan 6 $\mathrm{cm}$ adalah lebih efektif dan efisien karena mempunyai nilai $\mathrm{B} / \mathrm{C}$ tertinggi yaitu 1,76

\section{UCAPAN TERIMAKASIH}

Pada kesempatan yang berbahagia ini tidak lupa saya sampaikan terimakasih kepada LPPM Universitas Brawijaya yang telah memfasilitasi kegiatan penelitian ini. Ucapan terimakasih juga saya sampaikan kepada Arga yang telah membantu dalam pelaksanaan penelitian di lapang.

\section{DAFTAR PUSTAKA}

Ariffin. 2005. Dasar-dasar Klimatologi Pertanian. Fakultas Pertanian, Universitas Brawijaya. Tidak dipublikasikan

Badan Pusat Statistik. 2014. Impor Beras Menurut Negara Asal Utama, 2000-2014

Gomez, A.A dan A.K.Gomez. 1983. Statistical Procedures for Agricultural Research. $2^{\text {nd }}$ Ed. John Wiey \& Sons. New York.

Impron. 1999. Kapita Selekta Agroklimatologi. Tanggap Transpirasi terhadap Lingkungan. Jurusan Geofisika dan Meteorologi. FMIPA. IPB. Bogor.

lerna, A., G. Mauromicale. 2006. Physiological and Growth Response to Moderate Water deficit of off-season Potatoes in a Mediterranean Environment. Agric. Water Man. 82 : 193 - 209

Kozlowski, T.T. 1977. Ecophysiology Tropical Crops. Acad.Press.N.Y.

Onwueme, I.C. 1978. The Tropical Tuber Crop. John Wiley \& Sons. Chichester. New York. Brisbane, Toronto.

Rosernberg, N.J. 1974. Micro Climate. The Biological Environment. John Wiley \& Sonss, New York. Chichester. Brisbane. Toronto.

Sreekariyam dan Thiruvananthapuram. 2003. Nutritional Disorders in Tropical Tuber Crops. CTCRI. Kerala, India.

Suminarti, N.E dan U.Sulem. 2009. Peranan Mulsa Organik dalam Mempertahankan Kandungan Air Tanah dan Dampaknya Pada tanaman Kedelai (Glycine max L.) di 
Lahan Kering. Skripsi. Fakultas Pertanian, Universitas Brawijaya

Suminarti, N.E. 2009. Komposisi nutrisi dari berbagai jenis umbi dari tanaman umbi-umbian dan beras giling. Tidak dipublikasikan.

Suminarti, N.E. 2011. Teknik Budidaya Tanaman Talas (Colocasia esculenta (L.) Schott var. Antiquorum pad Kondisi basah dan Kering. Disertasi. Program Pasca Sarjana, Fakultas Pertanian, Universitas Brawijaya

Suminarti, N.E. 2012. Dasar Klimatologi. Modul. Jurusan Budidaya Pertanian, Fakultas pertanian, Universitas Brawijaya.

Tol, R.S.J.,K. Rehdanz and A. Calzadilla. 2010. The Economic Impact of more Sustainable Water Use In Agriculture : a Computable GENERAL Equilibrium of Analysis. J. Hydrol. 384 : $292-305$

Tjondronegoro, P., W. Prawiranata dan S.Harran. 1981. Dasar-dasar Fisiologi Tumbuhan I. Dept. Botani, FP, IPB. Bogor. 